УДК $81.11: 81^{\prime 253}$

М. А. Чепурна

\title{
ОСОБЛИВОСТІ ПЕРЕКЛАДУ ДІЛОВИХ ЛИСТІВ
}

Чепурна М. А. Особливості перекладу ділових листів.

У статті розглядаються особливості перекладу ділових листів та стереотипні кліше як компонент семантичної структури, які можна згрупувати за тематичною ознакою. Особливу увагу приділено абревіатурам та скороченим словам, створення та функціонування яких сприяє мовній економії і робить зміст більш зрозумілим та інформативним для певного кола фахівців.

Ключові слова: діловий лист, англійська мова, українська мова, абревіатура, скорочення, кліше, лексична одиниця.

(C) М. А. Чепурна, 2015. 
Чепурна М. А. Особенности перевода деловых писем.

В статье исследуются особенности перевода деловых писем, подробно рассматриваются стереотипные клише как компонент семантической структуры, которые можно сгруппировать по тематическому признаку. Особое внимание акцентируется на аббревиатурах и сокращенных словах, создание и функционирование которых способствуют языковой экономии и делает содержание текста более понятным и информативным для определенного круга специалистов.

Ключевые слова: деловое письмо, английский язык, украинский язык, аббревиатура, сокращение, клише, лексическая единица.

Tchepurna M. A. Peculiarities of Translating the Business Letters.

The article deals with the peculiarities of translating the business letters. We consider in detail the stereotype cliches as a component of semantic structures that may be grouped on thematic basis. Special attention is paid to the abbreviations and shortened words, with their creation and functioning promoting linguistic economy and making the content more understandable and informative for a specific circle of specialists.

Key words: business letter, English, Ukrainian, abbreviation, shortening, cliche, lexical unit.

Переклад міжнародної ділової документації має безліч особливостей. Тексти такого змісту обов'язково відповідають регламентованій формі. Основним завданням перекладача є дотримання необхідної форми та правильне розміщення адаптованого тексту.

При оформленні листа необхідно враховувати використання всіх мовних кліше та стильових особливостей матеріалу. Від роботи перекладача залежить результативність узаємодії партнерів.

Ведення справ 3 іноземним партнером найчастіше починається 3 листа, надісланого факсом чи електронною поштою. Ділові листи є важливим елементом зовнішньоекономічної діяльності. У країнах 3 розвиненою ринковою економікою ділові папери є невід'ємною частиною соціально-економічних відносин. Від ділового листа залежить пошук потенційних партнерів, можливість установлення чітких ділових контактів, а також пошук та освоєння нових ринків збуту продукції й надання послуг. Лист - це поширений вид документації, один із засобів обміну інформацією [3, с. 4].

Проблема лінгвістичних особливостей жанру ділового листування розглядається в роботах О. Ю. Дубенко, І. Б. Іванової, В.В.Калюжної, Т. М. Каменєвої, Т. Д. Пасічник, І. М. Підгайської, І. Д. Суханової, О. Б. Тарнопольського, С. П. Кожушко, І. Є. Шаргай, а також Л. ХемпЛайонза, Б. Херслі, С. Нормана, Р. Райкрофта, Р. Ернеста та інших.

Мета статті - проаналізувати структурні та лінгвістичні 
особливості ділових листів.

Діловий лист характеризується такими загальнотекстовими особливостями, як комунікативна спрямованість, смислова і логічна цілісність, зв'язність та завершеність, інформативна значущість. Крім того, діловий лист характеризується й специфічними ознаками, як-от: 1) об'єктивність; 2) конвенційність; 3) інструментальність; 4) прагматичність. Стилістичною нормою ділової кореспонденції $\epsilon$ стандартизація, яка фіксується в лексико-фразеологічних та синтаксичних напрямах. Діловому мовленню, як відомо, притаманна подібність мовленнєвих засобів і їх частотність, що є причиною появи кліше та стандарту [5, с. 5].

Діловий лист як частина сфери ділової комунікації виконує певну комунікативно-прагматичну функцію, під якою розуміють типову конвенційну мовленнєву реалізацію прагматичної мети автора, зумовлену нормами соціально-функціональної сфери. Загальною прагматичною метою адресанта є вплив на адресата. А мовні засоби, які реалізують цю мету, формують певну комунікативно-прагматичну функцію листа, що дає змогу адресатові інтерпретувати діловий листпрохання, пропозицію, скаргу, вибачення тощо [6, с. 10-11].

Стилі мовлення - це система взаємопов'язаних засобів, що слугують певній меті спілкування. В англійській мові виокремлюють переважно п'ять основних стилів мовлення: художній; публіцистичний; газетний; науковий; офіційно-діловий [4, с. 8].

Для отримання адекватного перекладу тексту слід враховувати стиль мовлення, оскільки ця належність має безпосередній уплив на вибір методів та прийомів перекладу. Крім того, вона визначає використання мовних засобів, скажімо, використання метафор у художньому стилі або їх відсутність в офіційно-діловому. Ділові листи безпосередньо належать до зразків офіційно-ділового стилю.

Офіційно-діловий стиль являє собою систему взаємопов'язаних мовних засобів, що мають на меті констатацію умов, які поєднують дві сторони у процесі діяльності. Він передбачає такі підмови: ділової документації; юридичних документів; дипломатії; військових документів.

При перекладі варто враховувати специфіку відповідного стилю, передусім зважати на особливу систему кліше, термінів та стійких виразів. Здебільшого лексика допомагає з'ясувати, до якого підстилю () М. А. Чепурна, 2015. 
належить текст: extra revenue, profit tax - фінансові документи; to ratify an agreement, extra-territorial status - мова дипломатії і т. ін. Це стосується й абревіатур, умовних символів, скорочень: \$-dollar, LtdLimited, M.P. - Member of Parliament, Gvt - government, ATAS - Air Transport Auxiliary Service. При перекладі скорочення переважно отримують розшифрування. Наприклад, ділові листи мають реквізити, де вказують адресу автора, дату, ім'я та адресу отримувача, а також наявні особлива фраза, якою закінчується лист, поділ на абзаци, параграфи та їхня нумерація.

Процес перекладу поділяють на «етапи» (В. Н. Комісаров) або «рівні» (В. Н. Крупнов) [2, с. 44]: розпізнання слова та загальної структури тексту; критичне осмислення оригіналу; передача отриманої інформації; завершальне осмислення перекладу в межах ширшого контексту.

Компонентом семантичної структури ділових листів $\epsilon$ стереотипні кліше, які можна згрупувати за тематичною ознакою: 1) замовлення; 2) пропозиція; 3) претензія, скарга; 4) запит; 5) повідомлення; 6) вибачення; 7) прохання. Існування в українській мові подібних груп висловлювань значно полегшує їх переклад українською мовою з англійської. Розглянемо кожну групу:

1) замовлення: With reference to the catalog you sent us we wish to place the following order [1, с. 45] - Ми хотіли б зробити замовлення, спираючись на каталог, який Ви нам надіслали; We are ordering ... each of the following items [1, с. 98] - Ми замовлясмо по .. одиниць кожного з таких виробів;

2) пропозиція: Based on your annual requirement of ... items, we can make the following offer [1, с. 45] - Виходячи з Вашої щорічної потреби в ... одиниць, ми можемо запропонувати Вам такі умови договору;

3) претензія, скарга: We regret that we must place the entire shipment at your disposal. Please let us know how you wish to dispose of same [1, с. 105] - Ми з жалем мусимо повернути Вам надіслані Вами товари. Просимо повідомити нам про те, як Ви пропонуєте розпорядитися вантажем;

4) запит: We are above all interested in information regarding the solvency and credit rating of the company [1, с. 98] - Особливо нас цікавить інформація щчодо платоспроможності фірми та ї̈ кредитоспроможності; 
5) повідомлення: We wish to inform you that your order № 30198 dated ... has been shipped today[1, с. 198] - Ми хочемо повідомити Вам, щзо замовлення № 30198 від ... було відвантажене сьогодні;

6) вибачення: We offer our apologies for the delay in delivery [1, с. 123] - Ми приносимо наші вибачення за затримку в поставиі; We will immediately make payment and would like to ask you to excuse the delay [1, с. 125] - Ми негайно проведемо оплату $i$ просимо Вас вибачити нам за затримку;

7) прохання: We shall (should) be obliged if you will (would) inform us... [2, с. 105] - Ми будемо (були б) вдячні, якщзо Ви повідомите (повідомили б) нам ...

На окрему увагу заслуговує вживання абревіатур і скорочених слів, що відіграють важливу роль у діловому спілкуванні. Абревіатури та скорочені слова слугують мовній економії, однак є зрозумілими для вузького кола фахівців. При перекладі варто застосовувати їх функціональні відповідники або описовий спосіб: a.a.r. (against all risks) - проти всіх ризиків; а.c. (account current) - поточний рахунок; advt. (advertisement) - оголошення, реклама; amt. (aтоиnt) - сума; B/E (bill of exchange) - mpamma; B/L (bill of lading) - коносамент; chq (cheque) - чек; C.N. (credit note) - кредитне авізо; D/P (documents against payment) - документи за готівковий розрахунок; еть. (embargo) - ембарго; тm. (nominal) - номінальний.

Серед синтаксичних структур, властивих діловим листам обох мов, вирізняються прості речення 3 ускладненою структурою. Англійське речення ускладнюється через використання інфінітивних конструкцій, герундію, дієприкметникових зворотів, що є засобами мовної економії та не $\epsilon$ характерними для українського ділового листа. При перекладі доцільно використовувати граматичну трансформацію: When unpacking the goods we experienced damages owing to the insufficient terms of transportation [1, с. 143] - При розпаковуванні товару ми помітили, щуо товари надійшли ушкодженими через невідповідні умови транспортування. У перекладі репліка зберігає суб'єкт дії, але іiі структура дещо змінюється. Герундій транспонується в іменну синтагму з прийменником і виконує в реченні функцію обставини часу.

У ситуаціях, коли англійське речення ускладнюється абсолютним дієприкметниковим або інфінітивним зворотом, ці форми трансформуються при перекладі в підрядне речення причини або (C) М. А. Чепурна, 2015. 
3'ясувальне: We offer you 3,000 tons of gas oil, delivery to be made in August [1, с. 149] - Ми пропонуємо 3000 тонн газойля, до того ж поставка відбудеться в серпні; You having been most successful in selling other goods, we would like to offer you our products [1, c. 156] Ми хотіли б запропонувати Вам нашу продукиію, оскільки Ви досягли значного успіху у продажі багатьох товарів. Інфінітивні конструкції відтворюються еквівалентно або трансформуються в підрядне речення умови: We expect the goods to be loaded at once [6, с. 143] - Mu очікуємо, що товари будуть відвантажені негайно.

В англійському діловому листі домінантними $є$ дійсний та умовний способи дії дієслова, які передаються еквівалентними формами в перекладі: We would be grateful if you could confirm that this company settles promptly on due dates [1, c. 154] - Ми були б Вам вдячні, якщяо Ви могли б підтвердити, щзо ияя компанія вирішує всі справи в установлені терміни. Імперативна форма дієслова, що вживається в українському діловому листуванні, не властива англійському.

Характерною рисою англійського ділового листа $є$ вживання стандартизованих кліше, які мають прагматичну спрямованість та забезпечують реалізацію категорії ділової ввічливості: We are looking forward to hearing from yоu - Ми з нетерпінням чекаємо на Ваму відповідь; We would appreciate your cooperation on this matter - Будемо вдячні за співпрацю; Thank you in advance for your cooperation Наперед дякуємо за допомогу; Awaiting your prompt reply - B очікуванні швидкої відповіді.

Ділове листування - є невід’ємним засобом зв'язку, що слугує для встановлення зв'язків між підприємствами, як вітчизняними, так i іноземними, сприяє економічному та політичному розвитку країни. Тому вміння правильно та коректно складати ділові листи $\epsilon$ надзвичайно важливим для будь-якої держави. I фахівці в цій справі повинні знати все до найменших подробиць й пам'ятати, що стиль написання листа до закордонної компанії є відмінним від звичного для нас, традиційного. Не слід забувати про структуру написання листа, оскільки послідовність викладу інформації, логічність змісту, простота i т. ін. $є$ кроком до успішного підписання контракту, залагодження конфліктів та підписання договорів. На окрему увагу заслуговує звертання до одружених та неодружених жінок, до чоловіків з особливими титулами тощо. Не менш важливими є знання 
пунктуації та специфіки перекладу листових штампів. Дотримання тих чи тих норм, зокрема й в офіційно-діловому стилі, допоможе перекладачеві розв'язувати складні проблеми ділового спілкування.

Перспективним $є$ розгляд англійського та українського ділових листів у комунікативно-прагматичному та когнітивному аспектах.

\section{Література}

1. Деловая переписка на английском и русском языках. 4000 стандартных фраз и выражений, 100 образцов деловой переписки по тематическим разделам. - М. Будапешт : Паннонарт, 1996. - 400 c.

2. Комиссаров В. Н. Теория перевода (лингвистические аспекты) В. Н. Комиссаров. - М. : Высшая школа, 1990. - 253 с.

3. Львовская 3. Д. Теоретические проблемы перевода / 3. Д. Львовская. - М. : Высшая школа, 1985. - 232 с.

4. Масальского В. І. Теорія і практика перекладу ділової документації : [навчальнометодичний посібник] / В. І. Масальского. - Донецьк : ДонНу, 2006. - 144 с.

5. Пономарів О. Д. Стилістика сучасної української мови / О. Д. Пономарів. Тернопіль, 2002. -248 с.

6. Радченко В. В Сопоставительный анализ английской, немецкой и русской деловой корреспонденции : автореф. дис. ... канд. филол. наук / В. В. Радченко. Пятигорск, 2005. $-23 \mathrm{c}$.

7. Савченко Т. В. Проблеми міжкультурної взаємодії в діловому спілкуванні : автореф. дис. ... канд. філол. наук / Т. В. Савченко. - К. , 1999. - 16 с.

8. Kenneth B. Business Email Basics [Електронний pecypc] / B. Kenneth. - Режим доступу : http://esl.about.com/od/businessenglishwriting/a/bizdocs_3. htm

Стаття надійшла до редакиї 30.03.2015 p. 